ORDINES MILITARES

COLLOQUIA TORUNENSIA HISTORICA

Yearbook for the Study of the Military Orders

XXI

ISSN (print) 0867-2008 / ISSN (online) 2391-7512

DOI: http://dx.doi.org/10.12775/OM.2016.002

SHLOMo LotaN

The Martin (Szusz) Department of Land of Israel Studies and Archaeology

Bar Ilan University

Ramat-Gan

5290002 Israel

shlomo-1@ramat-gan.muni.il

\title{
THE STATUS AND THE POSITION OF THE GERMAN STRUCTURE IN JERUSALEM IN THE $12^{\mathrm{TH}}-13^{\mathrm{TH}}$ CENTURIES
}

\section{KeYwords}

Jerusalem; Germans; Pilgrimage; Teutonic Order; Crusaders; Friedrich II; Hermann von Salza

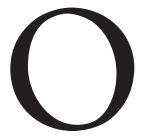

ne of the interesting questions arising from study of Jerusalem during the Crusader period is the status and position of the German Structure in the southeastern part of the city. We have information regarding this structure and its role, mainly during the golden age of the city in the i 2 th century, when it served as the capital of the Latin Kingdom of Jerusalem, and pilgrims, nobles and Christian clergy flocked to it and described the German compound in their accounts. One of the unsolved problems of Crusader research is what happened to the German structure after Jerusalem was conquered by the Ayyubids in I 87 , and especially during the I 3 th century, when the city briefly returned to Crusader control, between the years I $229-$ I $244 .{ }^{1}$

This article attempts to describe the phases of the German structure in the I 2 th century, as well as its status in the mid- I 3 th century until the end of the

1 For a general history of the Latin Kingdom of Jerusalem, see: J. Prawer, Histoire du Royaume Latin de Jérusalem, vol. II, Paris 1975; J. Richard, The Latin Kingdom of Jerusalem, vol. II A, B, Amsterdam 1979; C. Tyerman, God's War. A New History of the Crusades, Cambridge (Mass.) 2006.

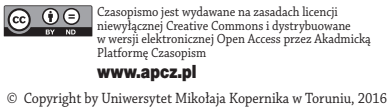


Crusader presence in Jerusalem. Moreover, I ask the question - did this structure leave any mark on the Teutonic Order tradition or its spiritual ideas, which could have linked Jerusalem to the heritage and tradition of the Teutonic Knights in the Middle Ages?

Jerusalem was first conquered by the Crusaders on July i 5, 1099. This was the end of a long and exhausting journey that began in Europe after the call for the liberation of the holy Christian places from Muslim control, including the Holy Sepulcher in Jerusalem. The city became a magnet for a new Christian population as well as the pilgrim movement, among them some German travelers. ${ }^{2}$

A medieval tradition accompanies the establishment of the German Structure in I I 27. According to this tradition, a German couple donated funds for a hospital, a hospice and a church while visiting the city on their pilgrimage, after realizing that there was no institution in the city to assist German pilgrims. Their aim was to support German pilgrims who needed medical assistance and accommodation during their visit to the holy city of Christianity. ${ }^{3}$ They established a church dedicated to Saint Mary, and near it other buildings, such as the hospice and the nearby hospital discovered in that area in recent excavations. ${ }^{4}$

The German hospital operated under the patronage of the Hospitallers (Order of Saint John of Jerusalem), which acted as the main nursing institute in Jerusalem, located at the heart of the city, close to the Holy Sepulcher church. In I 43 Pope Celestine II gave the Hospitaller Order authority over the German hospital and the nearby Church of St. Mary. The Pope stated that the leader of the medical German institution (Prior) and his associates would be of German origin, and would take care of other German pilgrims, thus contributing to the linguis-

2 T. Asbridge, The First Crusade. A New History, London 2004, pp. 295-327; C. Delano-Smith, The intelligent pilgrim: maps and medieval pilgrimage to the Holy Land, in: Eastward Bound, Travel and Travellers, 1050-1550, ed. R. Allen, Manchester 2004, pp. 116-123; T. Noonan, The Road to Jerusalem: Pilgrimage and Travel in the Age of Discovery, Philadelphia 2007, pp. 11-20.

3 James of Vitry, Historia orientalis seu Iherosolimitana, ed. J. Bongars, Gesta Dei per Francos, vol. 1, Hannover 1611, p. 1085: [...] honesto et religioso viro Teutonico, qui in civitate cum uxore sua morabatur, quatenus quoddam Xenodochium de bonis suis construeret, in quo pauperibus et infirmis Teutonicis hospitalitatem exhiberet.

4 A. J. Boas, Jerusalem in the Time of the Crusades: society, landscape, and art in the Holy City under Frankish rule, London 2001, pp. 125-126; D. Pringle, The Churches of the Crusader Kingdom of Jerusalem A Corpus, The city of Jerusalem, vol. 3, Cambridge 2007, pp. 228-229. Regarding the nursing activities of the German Hospital see: P. D. Mitchell, Medicine in the Crusades, Warfare, Wounds and the Medieval Surgeon, Cambridge 2004, pp. 75-78. 
tic separation between the central medical institution and the German structure, which was located in the southeastern part of the city.

One can learn about the German hospital in Jerusalem from the description offered by the German pilgrim Johan von Würzburg, who visited Jerusalem in the mid-I I 6os. The pilgrim described the German institution and its activity. $\mathrm{He}$ wrote that the German Institute was placed alongside the road leading to the Templar compound in the southeast part of the city. ${ }^{6} \mathrm{He}$ was referring to the Templum Salomonis, placed at the southern part of the Temple Mount, also known as the region of 'the Aqsa mosque' - which during the Crusader Kingdom acted as the Templar headquarters.

North of St. Mary's Church stood a hospice. This building served as a center for the Germans gathering in the city. One can note the visit of the noble Welf VI, Duke of Spoleto, who visited Jerusalem in I $67 .{ }^{8}$ The visit to the German hospice, the church and the hospital nearby resulted in a transfer of funds, agricultural products and grants of land to the Germans located in this compound. ${ }^{9}$

5 J. Delaville Le Roulx, Cartulaire général de l'Ordre des Hospitaliers de Saint-Jean de Jérusalem (1100-1310), vol. 1, Paris 1894, no. 154, p. 124: Quia igitur de Hospitali illo, quod ad susceptionem Teutonicorum ibidem constructum est, tam in regno Jherosolimitano quam in aliis mundi partibus.. ita videlicet ut de gente Theutonicorum priorem et servientes, quos idoneos cognoveritis, ibidem constituatis, qui Christi pauperibus in lingua sua respondere [...]; no. 155, pp. 124-125.

6 Peregrinationes Tres, Saewulf, John of Würzburg, Theodericus, ed. R. B. C. Huygens, Corpus Christianorum Continuatio Mediaeualis, vol. 139, Turnhout 1994, p. 133: [...] in qua via est hospitale cum aecclesia, quae fit de novo in honore sanctae Mariae et vocatur 'Domus Alemannorum.

7 S. Schein, Between Mount Moriah and the Holy Sepulchre: The Changing Traditions if the Temple Mount in the Central Middle Ages, Traditio 50 (1984), pp. 179-181; M. Barber, The Origins of the Order of the Temple, Studia Monastica 12 (1970), 2, pp. 220-225; H. Nicholson, Templars, Hospitallers, and Teutonic Knights: Images of the Military Orders, 1128-1291, Leicester 1995, pp. 22-23, 113-114; J. Burgtorf, The Central Convent of Hospitallers and Templars, History, Organization, and Personnel (1099/1120-1310), Leiden 2008, pp. 27-33; B. Z. Kedar, D. Pringle, 1099-1187: The Lord's Temple (Templum Domini) and Solomon's Palace (Palatium Salomonis), in: Where heaven and earth meet: Jeruslaem's sacred esplanade, ed. O. Grabar, Jerusalem 2009, pp. 142-147.

8 R. Röhricht, Die Deutschen im Heiliger Land. Chronologisches Verzeihnis derjenigen Deutschen, welche als Jerusalempilger und Kreuzfahrer sischer nachzuweisen oder wahrscheinlich anzusehen als Jerusalempilger und Kreuzfahrer, c. 650-1291, Aalen 1968, pp. 42-43; M.-L. Favreau-Lilie, The German Empire and Palestine: German pilgrimages to Jerusalem between the 12th and 16th century, Journal of Medieval History 21 (1995), pp. 322-324.

9 Tabulae Ordinis Theutonici ex tabularii regii Berolinensis codice potissimum, ed. E. Strehlke, Berlin 1869 (repr.: Toronto-Jerusalem 1975), no. 6 (1173), pp. 7-8: Amalricus I Hierosolymitanus rex donat b. Mariae s. domus hospitalis Theutonicorum 400 bisantios de funda Neapolitana, quatuor casalia in partibus $S$. Abrahae et Bethan, certos proventus frumenti et hordei de omnibus suis bonis in terries Ierusalem et Neapolis. 
This apparently contributed to the consolidation of the German enclosure and the elevation of its status in Jerusalem and the surroundings countryside.

In 1 i 76 , Princess Sophia of Holland was buried in the German compound in Jerusalem. The Princess visited the city during her pilgrimage and died there. The Germans buried her in their compound, probably in the Church, thus contributing to its uniqueness as a place of gathering for high-ranking German nobles. ${ }^{10}$

German activity in Jerusalem ceased with the occupation of the city by the Ayyubid troops and their leader Saladin, on October 2, I I $87 .{ }^{11}$ This was a few months after the fall of the Latin Kingdom into the hands of Muslims, following the immense defeat in the battle of Hattin in July i I $87 .{ }^{12}$ Jerusalem was lost and the Crusader institutions' activity halted, due to lack of Christian presence in the city. Most of the pilgrimages came to an end as well, and most of the former Crusader institutions ceased to operate. ${ }^{13}$ There are only a few descriptions by the few pilgrims who visited the city, and these do not mention any German activity in the city during the previous Crusader period. Therefore, it is possible that the German structure was abandoned.

In I I 98, a decade after the fall of Jerusalem into Ayyubid rule, and several years after the end of the Third Crusade in which the Crusader Kingdom returned to rule along the coast and the Galilee region, a new German Military Order was founded in Acre. ${ }^{14}$ This was based on the German nursing institute established in Acre in I I 90 , during the Third Crusade, under the leadership of the German ruler Frederick of Swabia. ${ }^{15}$

10 Annales Egmundani, ed. G. H. Pertz (Monumenta Germaniae Historica, Scriptores 16), Hannover 1859, p. 468.

11 P. W. Edbury, The Conquest of Jerusalem and the Third Crusade: Sources in Translation, Aldershot 1996, pp. 56-65; The Chronicle of Ibn al-Athir for the Crusading Period from al-Kamil fil-ta'rkikh, trans. D. S. Richards, vol. II, Aldershot 2008, pp. 330-335.

12 Chronique d'Ernoul et de Bernard le Trésorier, ed. L. Mas Latrie, Paris 1871, pp. 167-171; P. Herde, Die Kampfe bei den Hornern von Hittin and der Untergang des Kreuzritterheeres (3. and 4. Juli 1187). Eine historisch-topographische Studie, Römische Quartalschrift für christliche und Altertumskunde und Kirchengeschichte 61 (1966), pp. 1-50.

13 Regarding the journeys of the German pilgrims in Jerusalem, see: Wilbrand of Oldenburg (1211-1212) and Thietmar (1217-1218), D. Pringle, Pilgrimage to Jerusalem and the Holy Land, 1187-1291, Farnham 2012, pp. 87-92, 111-113.

14 L'Estoire de Eracles Empereur et la Conqueste de la Terre d'Outremer (Recueil des Historiens des Croisades. Historiens Occidentaux (further: RHC Occ.) II), Paris 1859, pp. 227-228; M-L. Favreau, Studien zur Frühgeschichte des Deutschen Ordens (Kieler historische Studien 21), Stuttgart 1974, pp. 64-72; N. E. Morton, The Teutonic Knights in the Holy Land 1190-1291, Woodbridge 2009, pp. 11-13.

15 Chronicon breve fratris, ut videtur, ordinis Theutonicorum, ed. G. Waitz (Monumenta Germaniae Historica, Scriptores 24), Hannover 1879, p. 153: Imperator Fridericus, pacato imperio, 
Although based at Acre, the new German Military Order bore the name of Saint Mary and the memory of Jerusalem (Ordo domus Sancte Marie Theutonicorum Hierosolymitanorum). ${ }^{16}$ Although it seems that only a few of its members were familiar with German activity in Jerusalem in the mid- $\mathrm{I} 2$ th century, ${ }^{17}$ giving the newly-established Military Order this name sought to link its history to the events which had occurred in Jerusalem, claiming a connection to the city's glory similar to that of the well-established Military Orders - the Hospitallers and the Templars, who had reached their height during the I 2 th century. ${ }^{18}$

In the early i 3 th century the Teutonic Knights tried to enhance the position of their order in the Crusader Kingdom. This came about through a series of land and property acquisitions in the villages of the Galilee region, as well as building and strengthening the eastern part of the city of Acre, which became their center. ${ }^{19}$ Yet despite this, the memories of Jerusalem, controlled at that time by the

cum filio suo Friderico duce Suevorum et magno procerum et aliorum comitatu Terram Sanctam visitavit. Sed cum quadam die lavaretur in flumine periit, et dictus filius eius exercitum strennue rexit, sed et ipse in brevi obiit et in ecclesia sancte Marie hospitalis Theutonicorum, quam pater et ipse inchoaverant sepultus fuit; U. Arnold, Entstehung und Frübzeit des Deutschen ordens, in: Die geistlichen Ritterorden Europas, ed. J. Fleckenstein, M. Hellmann (Vorträge und Forschungen XXVI), Sigmaringen 1980, pp. 89-90, 94; idem, Vom Feldspital zum Ritterorden, Militarisierung und Territorialisierung des Deutschen Ordens (1190 - ca. 1240), in: Balticum. Studia z dziejów polityki, gospodarki i kultury XII-XVII wieku ofiarowane Marianowi Biskupowi w siedemdziesiąta rocznicę urodzin, ed. Z. H. Nowak, Toruń 1992, pp. 25-36.

16 Die Statuten des Deutschen Ordens nach seinen ältesten Handschriften, ed. M. Perlbach, Halle 1890, p. 159: [...] ea spe et fiducia, ut terra sancta christiano cultui restituta in civitate Sancta Ierusalem domus fieret eiusdem ordinis principalis, mater, caputpariter et magistra; W. Hubatsch, Quellen zur Geschichte des Deutschen Ordens (Quellensammlung zur Kulturgeschichte 5), Göttingen 1954, pp. 26-31; see also: Tabulae Ordinis Theutonici (as n. 9), no. 183 (1298), p. 165: [...] ordinis fratrum hospitalis sancte Marie Theutonicorum in Ierusalem [...]; Tabulae Ordinis Theutonici, no. 210 (1337), p. 201: [...] fratres ordinis hospitalis beate Marie domus Theutonicorum Ierosolimitani, quorum sancta religio ab imperialibus beneficium.

17 Favreau (as n. 14), pp. 12-17; U. Arnold, Jerusalem und Akkon. Zur Frage von Kontinuität oder Neugründung des Deutschen Ordens 1190, Mitteilungen des Instituts für österreichische Geschichtsforschung 86 (1978), pp. 416-432; G. Müller, Jerusalem oder Akkon? Über den Anfang des Deutschen Ordens nach dem gegenwärtigen Stand der Forschung, Bad Münstereifel 1989, pp. $12-15$.

18 D. Pringle, The Military Orders in the Cities of the Holy Land, in: Les Ordres Militaires dand la Ville Médiévale (1100-1350), ed. D. Carraz, Clermont-Ferrand 2013, pp. 79-81.

19 R. Frankel, Topographical Notes on the Territory of Acre in the Crusader Period, Israel Exploration Journal 38 (1988), 4, pp. 249-259; S. Lotan, Governing the Teutonic Order from "Outremer" The Teutonic Headquarters Competing in the Last Era of the Latin Kingdom of Jerusalem, in: Herrschaft, Netzwerke, Brüder des Deutschen Ordens in Mittelalter und Neuzeit. Vorträge der Tagung der Internationalen Historischen Kommission zur Erforschung des Deutschen Ordens in 
Ayyubids, remained in their name as well as in their spiritual traditions. ${ }^{20}$ Among other biblical figures, the Teutonic Order added King David, the courageous biblical leader of Jerusalem, to their tradition and their chronicles of the late medieval period. $^{21}$

The first opportunity to recapture Jerusalem and restore it to its former glory was provided only during the Sixth Crusade, in I228-I229, with the arrival of Roman Emperor Frederick II to the Crusader Kingdom. ${ }^{22}$ Frederick II landed with his army in Acre, receiving partial support from the Kingdom's population. Church leaders and most of the military orders excommunicated the Emperor, leaving him with support mainly from the Teutonic Knights. ${ }^{23}$

The Teutonic warriors and their leader, Hermann von Salza, accompanied the Emperor on his journey from Acre to Jerusalem, after his halt in the city of Jaffa, where he signed a peace agreement with Al-Kāmil, the Ayyubid Sultan of Egypt, on I 8 February I 229. ${ }^{24}$ The way to Jerusalem opened for the Crusaders, and they

Marburg 2010, ed. K. Militzer, (Quellen und Studien zur Geschichte des Deutschen Ordens 72), Weimar 2012, pp. 31-33.

20 U. Arnold, Ritter und Priester, in: Acht Jahrhunderte Deutscher Orden in Nordwesteuropa (Ausstellungkatalog), ed. U. Arnold, Alden Biesen 1992, pp. 11-13; G. Wichert, Die Spiritualität des Deutschen Ordens in seiner mittelalterlichen Regeln, in: Die Spiritualität der Ritterorden im Mittelalter (Ordines Militares. Colloquia Torunensia Historica VII), ed. Z. H. Nowak, Toruń 1993, pp. 136-137; K. Militzer, Von Akkon zur Marienburg, Verfassung, Verwaltung und Sozialstruktur des Deutschen Ordens 1190-1309 (Quellen und Studien zur Geschichte des Deutschen Ordens 56), Marburg 1999, p. 38; R. Czaja, Die Identität des Deutschen Ordens in Preussen, in: Cura Animarum, Seelsorge im Deutschordensland Preußen, ed. S. Samerski, Köln 2013, p. 47.

21 Peter von Dusburg Chronik des Preussenlandes, trans. K. Scholz, D. Wojtecki (Ausgewählte Quellen zur deutschen Geschichte des Mittelalters XXV), Darmstadt 1984, Chron. Prologus, pp. 34, 46: David enim secundum cor Dei in regnum fidelium exaltatus, ut propheta futurorum prescius; p. 70: [...] cum David pugnaturus contra Golyam diceret, pp. 80-82; M. Wüst, Studien zum Selbstverständnis des Deutschen Ordens im Mittelalter (Quellen und Studien zur Geschichte des Deutschen Ordens 73), Weimar 2013, pp. 55-56, 75, 133.

22 U. Arnold, Die Staufer und der Deutsche Orden, in: Medieval Spirituality in Scandinavia and Europe. A Collection of Essays in Honour of Tore Nyberg, ed. L. Bisgaard, C. S. Jensen, J. Lind, Odense 2001, pp. 147-148; B. Hechelhammer, Kreuzzug und Herrschaft unter Friedrich II. Handlungsräume von Kreuzzugspolitik (1215-1230) (Mittelalter-Forschungen 13), Ostfildern 2004, pp. 296-306.

23 Historia Diplomatica Frederici Secundi, ed. J. L. A. Huillard-Bréholles, vol. 3, Turin 1963, pp. 102-110, 135-140; M. Powell, Patriarch Gerold and Frederick II: The Matthew Paris Letter, Journal of Medieval History 25 (1999), 1, pp. 19-26; B. Weiler, Gregory IX, Frederick II, and the Liberation of the Holy Land, in: The Holy Land, Holy Lands, and Christian History, ed. R. N. Swanson, Woodbridge 2000, pp. 197-198; L. Ross, Frederick II: Tyrant or Benefactor of the Latin East?, Al Masāq 15 (2003), 2, p. 154.

24 L'Estoire de Eracles (as n. 14), pp. 373-374; Historia Diplomatica Frederici Secundi (as n. 23), vol. 3, pp. 86-90; T. Mastnak, Crusading Peace. Christendom, the Muslim World, and Western 
also gained control of most of the city, including all its former Crusader structures, but without the Temple Mount which remained under Muslim control. ${ }^{25}$

This agreement was opposed by the Church leaders, but the emperor did not hesitate and continued on to Jerusalem, where he was crowned in the Holy Sepulcher as King of Jerusalem on I 8 March I $229 .{ }^{26}$

The Teutonic Knights, as the Emperor's followers and the most supportive organization, received generous grants honoring their support. The Emperor donated to the Teutonic Order structures and lands in the western part of the city, in the region of the royal palace - Curia Regis in the western part of the city, on the Armenian street, near St. Thomas church, as well as six 'carruca' in an open field nearby. This might be present day Armenian Garden, south of the Curia Regis and St. Thomas Church next to the Citadel. The structure of the Curia Regis was recently exposed in archaeological excavations, which emphasized its uniqueness as a central part of the defense system. The Teutonic Order was also awarded a grant of a building next to the Church of the Holy Sepulcher, the focus of the small Christian community populating the northwest part of the city. ${ }^{27}$

The Teutonic Order also received the role of protecting the city wall, mainly in the north and west of the city, where they were asked by the emperor to rebuild the walls. ${ }^{28}$ In addition to these grants, the Emperor gave the Teutonic Order control

Political Order, Berkeley 2002, pp. 148-152; Y. Friedman, Peacemaking, Perceptions and Practices in the Medieval Latin East, in: The Crusades and the Near East, ed. C. Kostick, London 2011, pp. 238-239; H. Takayama, Frederick II's Crusade: an example of Christian - Muslim diplomacy, Mediterranean Historical Review 25 (2010), 2, pp. 174-175.

25 Historia Diplomatica Frederici Secundi (as n. 23), vol. 3, pp. 96-97: [...] ut peregrine de cetero processum liberum habeant ad sepulcrum Domini et securum inde regressum, excepto videlicet quod cum Saraceni in quadam veneratione maxima Templum habeant et illuc secundum ritum eorum ad orandum (a) in modum Saracenorum peregrinorum accedant.

26 Coronatio Hierosolimitana 1229, ed. L. Weiland (Monumenta Germaniae Historica, Constitutiones et Acta Publica Imperatorum et Regum 2), Hannover 1896, no. 121, p. 162: Et dum de restitutione Terre Sancte tractaretur, dominus Iesus Christus sua solita providential ita ordinavit, quod soldanus restituit domino imperatori et christianis civitatem sanctam Ierusalem cum suis tenimentis [...]; no. 122, p. 165: [...] soldanus Babylonie restituit nobis civitatem sanctam Ierusalem, locum videlicet ubi pedes Christi steterunt, locum etiam ubi veri adoratores in spiritu et veritate Patrem partum adorant; T. C. Van Cleve, The Emperor Frederick II of Hohenstaufen Immutator Mundi, Oxford 1972, pp. 224-226; D. Abulafia, Frederick II. A Medieval Emperor, London 1988, pp. 185-188.

27 Tabulae Ordinis Theutonici (as n. 9), no. 69 (1229), p. 55: [...] in civitate sua Ierusalem domum quondam Balduini Regis sitam in ruga Armeniorum prope ecclesiam s. Thomae [...] sex carrucatas terrae; Tabulae Ordinis Theutonici (as n. 9), no. 70, pp. 55-56: [...] domo sitam iuxta ecclesiam s. Sepulcri.

28 Continuation de Guillaume de Tyr de 1229 à 1261, dite du manuscript de Rothelin (RHC Occ II), Paris 1859, p. 529: Li Chrestien avoient commencié a fermer, de leur ausmosnes que il metoient, la citépar deverz la porte Saint Estienne, et avoient fait un pou del mur, et ne sai quantes tornelles. 
over the Citadel. This fortification was used as a central point of the city's defense system, a command and control center in a city which knew many attacks by the Ayyubids. It became the center of the Teutonic rule of Jerusalem, similar to their compound in Tyre, which also played a major role in the defense of the Crusader city. ${ }^{29}$ It is likely that the Emperor's confidence in the Teutonic brethren led to this valuable donation, establishing the status of the Teutonic Knights in Jerusalem.

The citadel served as a shelter for the city's Christian population during the Muslim attacks on the city. The Teutonic stand in the citadel took place despite the poor state of the kingdom in the mid- I 3 th century, mainly due to the political and military situation in Jerusalem, which suffered several attacks from the Ayyubids and their leader, Al Nāssir Dāwūd, ruler of Kerak, in I 239. He attacked the city and destroyed its walls, also sowing much destruction in the Citadel..$^{\circ}$

In the early I 240 s, Jerusalem was strengthened by the Crusaders, along with additional land and settlements in its vicinity, following the result of the so-called Barons' Crusade (I239-I 24I); but despite this, the city's remoteness from the coastal area prevented the strengthening of its status in the Crusader Kingdom. ${ }^{31}$

The final accord in Jerusalem's history in the Crusader period took place in August I 244, when nomadic tribes descended on the city and attacked Jerusalem's population and its churches. The destruction was enormous, the city was looted and destroyed, and the Khwarizmian tribes even damaged the tombs of the Crusader kings in the Holy Sepulcher. ${ }^{32}$

29 H. Prutz, Die Besitzungen des Deutschen Ordens im Heligen Land, Leipzig 1877, p. 36; C. N. Johns, Pilgrim' Castle (Atlit) David's Tower (Jerusalem) and Qal'at ar-Rabad (Ajlun), ed. D. Pringle, Aldershot 1997, p. 167; Philip de Novare, The Wars of Frederick II against the Ibelins in Syria and Cyprus, transl. by John L. La Monte, New York 1936, p. 51.

30 P. Jackson, The Crusades of 1239-41 and their aftermath, Bulletin of the School of Oriental African Studies 50 (1987), p. 39; R. Ellenblum, Frankish Castles, Muslim Castles, and the Medieval Citadel of Jerusalem, in: In Laudem Hierosolymitani. Studies in Crusades and Medieval Culture in Honour of Benjamin Z. Kedar, ed. I. Shagrir, R. Ellenblum, J. Riley-Smith, Aldershot 2007, pp. 106-107.

31 De gloriosa pace et treugis inter Christianos et Sarracenos per comitem Ricardum captis, in: Matthew Paris, Chronica majora (Rolls Series 57, vol. IV), London 1872-1883, pp. 142-143; M. Lower, The Baron's Crusade. A Call to Arms and its Consequences, Philadelphia 2005, pp. 175-177.

32 Chronica de Mailros, ed. J. Stevenson, Edinburgh, 1835, pp. 158-163; Regesta Regni Hierosolymitani 1097-1291, ed. R. Röhricht, Innsbruck, 1893-1904, no. 1123 p. 299: [...] Tartaros Urbem Sanctam cepisse et S. Sepulchrum vastavisse; C. Cahen, The Turks in Iran and Anatolia before the Mongol Invasions, in: A History of the Crusades, The Later Crusades, 1189-1311, vol. II, ed. R. L. Wolff, H. W. Hazard, Philadelphia 1962, pp. 670-674; see also the Emperor's description of the terrible loss of Jerusalem in 1244: Historia Diplomatica Frederici Secundi (as n. 23), vol. 6, Turin 1963, p. 237: [...] quod tota regni Hierosolymitani terra quam christiani possederant trans Jordanem, retentis sibi villis et montanis aliquibus, christianis restituta [...] Quo 
What was then the fate of the German compound in the southeast part of the city? Is there any evidence that Teutonic writers mentioned the former German activities in the 12 th century?

Examination of Medieval sources, pilgrims' descriptions and chronicles of the period, shows that the Teutonic brethren, gaining a high status as defenders of the city in the first half of the 13 th century, chose to focus on and protect the western parts of the city - the town citadel and the Armenian Quarter, near the Church of the Holy Sepulcher and in the Patriarch Quarter in the northern part of the city.33 The German compound, the hospital building and the hospice in the southeastern part of the city received no mention at the time.

The pilgrims' descriptions and the Military Order's documents contain no specific reference to any activity in that compound. The structure may not have been returned to its previous holders in the I 2 th century, due to the remoteness and isolation of this region from the heart of Christian activity in the northern and western parts of the city. One should remember that the German structure stood close to the area of the Temple Mount, which remained under Muslim control after the peace agreement in I229. It is likely that the Teutonic brethren posted in Jerusalem did not wish to stay on the border zone between the two rivals, and chose to operate near a Christian area in the western and northern parts of the city, between the Citadel and Saint Stephen's Gate. ${ }^{34}$

The Temple Mount returned to Christian rule in I243, according to the agreement initiated by the Templars and the Ayyubids from Damascus. The former headquarters of the Templars was returned for one year only, until the conquest of the city in I244, and there is no evidence that the Templars managed to establish any concrete presence or create facts on the ground in that area and its surroundings, in the vicinity of the former German structure, in such a short time. ${ }^{35}$ Teutonic sources present no evidence of a change in the status of the German holdings in the southern part of the city at that time.

According to late medieval chronicles of the Teutonic Order from the late $15^{\text {th }}$ and early I 6 th century, hundreds of years after the loss of Jerusalem, the Teutonic

superveniente, perfide gentis metu, de civitate Hierosolymitana [...] sepulchro Domini violato, quod fuerat fidei christiane visibile notrimentum.

33 S. Lotan, The Symbolism of Jerusalem in the Traditions of the Teutonic Military Order, Zapiski Historyczne 75 (2010), 4, pp. 14-16.

34 G. J. Wightman, The Walls of Jerusalem, From the Canaanites to the Mamluks, Sydney 1993, pp. 283-285.

35 M. L. Bulst-Thiele, Zur Geschichte der Ritterorden und des Königreichs Jerusalem im 13 Jahrhundert bis zur Schlacht bei La Forbie am 17. Okt. 1244, Deutsches Archiv 22 (1966), pp. 218-224; I. Berkovich, Templars, Franks, Syrians and the Double Pact of 1244, in: The Military Orders, Politics and Power, vol. 5, ed. P. Edbury, Farnham, 2012, pp. 86-88. 
Order started paying tribute to the activities and tradition of the religious institution and its heritage during the Crusader period. ${ }^{36}$ The 'Younger Chronicles of the Grand Masters' (Jüngere Hochmeister Chronik) and the 'Chronicle of the Four Orders from Jerusalem' (Chronik der vier Orden von Jerusalem), tell the story of the creation of the four orders in the Crusader Kingdom - the establishment of the Orders of the Hospitallers, the Templars, the Teutonic Order and the canons of the Holy Sepulcher in Jerusalem..$^{37}$

The 'Chronicle of the Four Orders from Jerusalem' emphasized the place of Mount Zion in the history of the religious orders. According to the 'Chronicle of the Four Orders from Jerusalem', Empress Helena, mother of the Byzantine Emperor Constantine, established two hospitals for the benefit of the city population at Mount Zion in the 4th century. Several centuries later, the Crusader ruler Baldwin I (I IO0-III8) made major contributions, making these two hospitals the medical structures of the Hospitallers and the Teutonic Order. ${ }^{38}$

This chronicle raised questions about the location of the buildings listed. There are many hints that link the Hospitallers to the compound in the city center, next to the Church of the Holy Sepulcher. This site is wide and impressive, as well as being documented in Crusader sources and archaeological excavations conduct-

36 U. Arnold, Deutschordenshistoriographie im Deutschen Reich, in: Die Rolle der Ritterorden in der mittelalterlichen Kultur (Ordines Militares. Colloquia Torunensia Historica III), ed. Z. H. Nowak, Toruń 1985, pp. 77-80; J. Sarnowsky, Das historische Selbstverständnis der geistlichen Ritterorden, Zeitschrift für Kirchengeschichte 110 (1999), pp. 315-330.

37 Die Jüngere Hochmeisterchronik, ed. T. Hirsch (Scriptores rerum Prussicarum. Die Geschichtsquellen der Preussischen Vorzeit bis zum Untergane der Ordensherrschaft 5), Leipzig 1874 (repr.: Frankfurt/Main 1965), pp. 1-148; Die Chronik der Vier Orden von Jerusalem, ed. W. Hubatsch, U. Arnold (Scriptores rerum Prussicarum. Die Geschichtsquellen der Preußischen Vorzeit bis zum Untergane der Ordensherrschaft 6), Frankfurt/Main 1968, pp. 106-164; K. Elm, Kanoniker und Ritter vom Heiligen Grab. Ein Beitrag zur Frühgeschichte der Palästinensischen Ritterorden, in: Die geistlichen Ritterorden Europas (as n. 15) Sigmaringen 1980, pp. 141-169.

38 Die Jüngere Hochmeisterchronik (as n. 37), p. 48: Ende dese heilige keyserinne Helena dede alle die heilige steden bynnen Iherusalem ende dair omtrent [...]; Die Jüngere Hochmeisterchronik (as n. 37), p. 49: Ende van dat sinte Helena alle die heilige steden dede repariren ende tymmeeren ende die twe hospitalen van onse lieve vrouwe ende van sinte Johan had doen maken.. in dem vurscreven heiligen huyse tot dat die Duytsche oirde gesticht wert [...]; J. Sarnowsky, Historical writing in military orders, 12th-16th centuries, in: As Ordens Militares e as Ordens de Cavaleria entre o Ocidente e o Oriente. Actas do V Encontro sobre Ordens Militares, Palmela, 15 a 18 de Fevereiro 2006, ed. I. C. F. Fernandes, Palmela 2009, pp. 118-119; Wüst (as n. 21), pp. 76, 133. 
ed in the area. ${ }^{39}$ Even the German nursing structure was not located in Mount Zion, but rather in the southern part of the city, close to the Temple Mount. ${ }^{40}$

Mount Zion became the site for the activities of the rare Christian presence in Jerusalem in the Mamluk period, at the end of which these chronicles were written ( 15 th- I 6 th centuries). The Christian activities were conducted mostly by the Franciscans, who had been given the rights of protection of Christians in the Holy Land (Custodia Terrae Sanctae). Mount Zion became their main place of activity; separate from Jerusalem, but in an area where significant Christian events took place (Jesus's imprisonment and the Cenacle). ${ }^{41}$ Christian pilgrims used Mount Zion as the starting point of a religious tour of the city and its most important Christian sites called 'Circulus Sanctus', included the Via Dolorosa and the Church of the Holy Sepulcher. ${ }^{42}$

Adapting the Hospitallers' and the Teutonic Order's traditions to Mount Zion tied this place to the core of the Christian activities in Jerusalem at the time. The former German structure known from the i 2 th century lost its uniqueness to the Christian buildings on Mount Zion, once again because of the remoteness and isolation of this place from the main Christian activity in the heart of the city. It seems that the late Teutonic chronicles adopted what was familiar at that time,

39 S. Edgington, Administrative Regulations for the Hospital of St. John in Jerusalem dating from the 1180s, Crusades 4 (2005), pp. 21-37; B. Z. Kedar, A Note of Jerusalem's Bimāristan and Jerusalem's Hospital, in: The Hospitallers, the Mediterranean and Europe: Festschrift for Anthony Luttrell, ed. K. Borchardt, N. Jaspert, H. J. Nicholson, Aldershot 2007, pp. 10-11; D. Pringle, The Layout of the Jerusalem Hospital in the Twelfth Century: Further Thoughts and Suggestions, in: The Military Orders: By Land and by Sea, vol. 4, ed. J. Upton-Ward, Aldershot 2008, pp. 93-97; J. Hasecker, Die Johanniter und die Wallfahrt nach Jerusalem (1480-1522), Göttingen 2008, pp. 247-250; about the new discoveries in the Hospitaller compound in Jerusalem, see also: I. Berkovich, A. Re'em, The Location of the Crusader Hospital in the Muristan: A Reassessment, in: The ancient Remains below the Church of the Redeemer, the Muristan and its Surroundings, ed. D. Vieweger, S. Gibson, Oxford 2016, pp. 193-220.

40 For the location of the German structure in the Old City of Jerusalem, see: A. Metav, Jerusalem - one square kilometer: the Old City - a guide to the sites, Jerusalem 2015, pp. 79-80 (Hebrew).

41 M. W. Baldwin, Franciscan Missions to the East in the Thirteenth and Fourteenth Centuries, in: History of the Crusades, The Impact of the Crusades on the Near East, vol. 5, ed. N. P. Zacour, H. W. Hazard, Madison 1985, pp. 452-489; S. Schein, From the 'City of the Holy Sepulchre' to the 'City of the Humanity of Christ', in: Gateway to the Heavenly City: Crusader Jerusalem and the Catholic West (1099-1187), Aldershot 2005, pp. 80-81, 86-87; A. Jotischky, The Franciscan Return to the Holy Land (1333) and Mt Sion: Pilgrimage and the Apostolic Mission, in: The Crusader World, ed. A. J. Boas, London 2016, pp. 241-250.

42 S. Schein, Latin Hospices in Jerusalem in the Late Middle Ages, Zeitschrift des Deutschen Palastina-Vereins 101 (1985), 1, pp. 89-91; Y. Friedman, Sacred and Secular in the Fourteenth-Century Pilgrims' Conception of the Holy Land, in: Eretz Israel in the Mamluk Period, ed. Y. Drori, Jerusalem 1993, pp. 128-141 (Hebrew). 
choosing to establish the German institution on Mount Zion without anchoring it to its former tradition.

New archaeological excavations conducted in 20 I I by the Israel Antiquities Authority in the Tomb of King David on Mount Zion and in the Franciscan monastery courtyard located nearby discovered the remains of the Christian holdings from the Mamluk period. The Franciscan cloister courtyard served the pilgrims' hostel complex in the city. Close to this courtyard stood the Tomb of David, and over it the Cenacle room, constructed as a magnificent example of Gothic architecture. ${ }^{43}$ This strengthened the hypothesis that the site at Mount Zion was important to Christian pilgrims visiting Jerusalem, among them some German travelers such as Felix Fabri (I 480, I 483) and Paul Walther von Guglingen (I 482$).^{44}$

It seems that the Teutonic Order also embraced this tradition on Mount Zion as part of the geographical developments that took place in Jerusalem during the Mamluk period, adopting the spiritual centrality of Mount Zion in the Christian experience. Later chronicles of the Teutonic Order include some praise of the centrality of Mount Zion. ${ }^{45}$ There is no mention of the memory of the German compound, the original German settlement in Jerusalem during the Crusader period in the $\mathrm{I} 2$ th century.

The German compound could have been forgotten, remaining merely a part of the German heritage in Jerusalem. The archeological excavations conducted in the southeast part of the city in 1968 led to exposure of the compound and its uniqueness in the Crusader period. On the site, the diggers revealed a building of a Romanesque church with a nave, two aisles and apses. ${ }^{46}$ The building was decorated with elbow-columns - a unique decorative element from the Latin Kingdom

43 A. Re'em, Jerusalem, Mount Sion, Hadashot Arkheologiyot, Excavations and Surveys in Israel 124 (2012) (Internet); A. Mashiah, The Conservation of David's Tomb on Mount Sion, Dvar Avar (July 2013), pp. 14-17 (Hebrew).

44 Fratris Felicis Fabri Evagatorium in Terrae Sanctae, Arabiae et Egypti peregrinationem, vol. 1, ed. K. D. Hassler, Stuttgart 1843, p. 240; W. Carls, Felix Fabri, Die Sionpilger, Berlin 1999, pp. $77-$ -89; Pauli Waltheri Guglingensis Itinerarium, ed. M. Söllweck, Tübingen 1882, pp. 114-115; C. Zrenner, Die Berichte der europäischen Jerusalempilger 1475-1500, Frankfurt/Main 1981, pp. 42-50; K. M. Rudy, Virtual Pilgrimages in the Convent: Imagining Jerusalem in the Late Middle Ages, Turnhout 2011, pp. 21-23.

45 Die Jüngere Hochmeisterchronik (as n. 37), pp. 44-45: berch van Syon; p. 46: [...] in Davids stadt op ten berch van Syon ende bemuerdense om ende mactse starck ende leyde dar ridders ende soldeners in [...].

46 A. Ovadiah, A Crusader Church in the Jewish Quarter of Jerusalem, Eretz Israel 11 (1973), pp. 208-212 (Hebrew). 
structures. ${ }^{47}$ In the southern part of the church stood the hospital compound, and on the north side the hospice. These buildings were all connected together by passageways and open courts, forming a united compound. ${ }^{8}$

Today, the German compound receives special attention due to its location near the passage to the Temple Mount and its position in the heart of the Jewish Quarter in the old city of Jerusalem. There are plans to use the site in the future as a public open area and an archaeological exhibition center. ${ }^{49}$ Perhaps when this plan is realized, the German structure will return to its glory from the Crusader period in the Middle Ages.

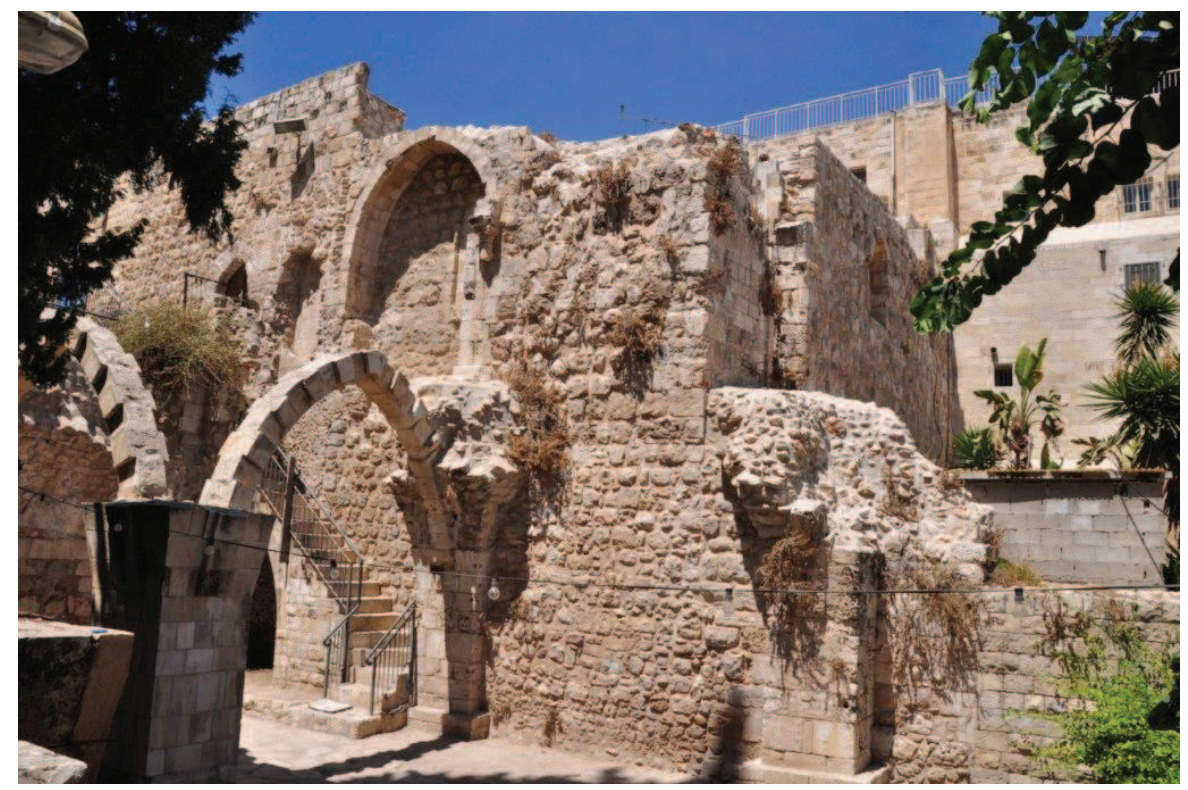

Illustration: Remains of the German hospital in Jerusalem

47 E. Grabiner, The Elbow Column: An Original Crusader Creation, in: Knights of the Holy Land, The Crusader Kingdom of Jerusalem, ed. S. Rozenberg, Jerusalem 1999, pp. 192-201.

48 M. Ben Dov, The Restoration of St. Mary's Church of the German Knights in Jerusalem, in: Ancient Churches Revealed, ed. Y. Tsafrir, Jerusalem 1993, pp. 140-142.

49 M. Edelkopf, The German Church in the Old City of Jerusalem: conservation and development plan, Israel Antiquities Authority, Jerusalem 2008 (Hebrew); A. Amiri, The German Church in Jerusalem, the Old City, a land program, general provisions for conservation, Israel Antiquities Authority - the Conservation unit, Jerusalem 2009 (Hebrew). 
Plan of Jerusalem in the Crusader Period
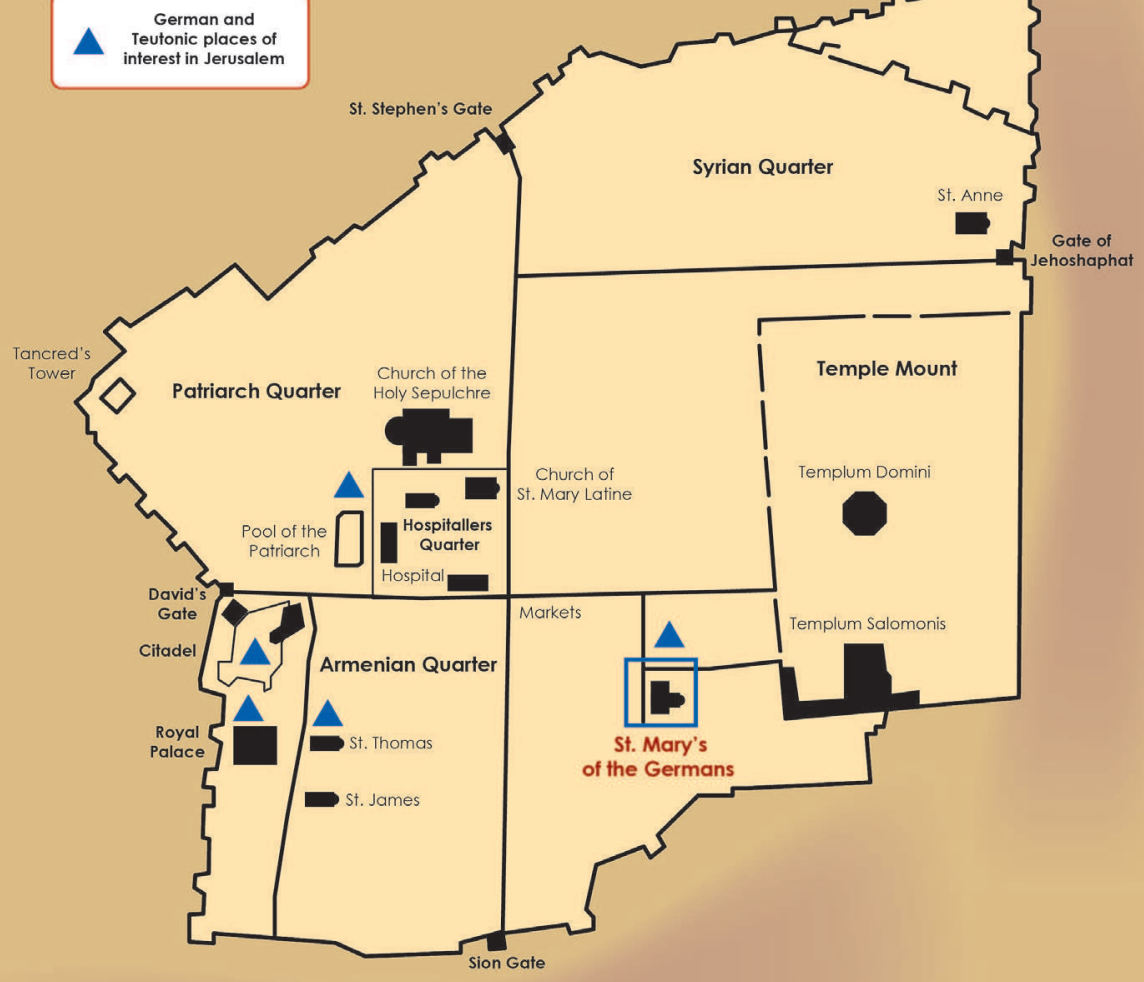

St. Mary of Mt. Sion 


\section{SOURCES AND Literature}

“Annales Egmundani.” In Monumenta Germaniae Historica Scriptores, edited by Georg H. Pertz. Vol. I 6. Hannover: Impensis Bibliopolii Aulici Hahniani, I 859.

Bongars, Jacques., edit. "James of Vitry, 'Historia orientalis seu Iherosolimitana”. In Gesta Deiper Francos. Vol. I. Hannover: Aubrii, I 6 I I.

"Chronicon breve fratris, ut videtur, ordinis Theutonicorum." In Monumenta Germaniae Historica Scriptorum, edited by Georg Waitz. Vol. 24. Hannover: Impensis Bibliopolii Aulici Hahniani, I 879 .

"Continuation de Guillaume de Tyr de I 229 à I 26 I, dite du manuscript de Rothelin." In Recueil des Historiens des Croisades. Historiens Occidentaux. Vol. 2. Paris: Académie des inscriptions et belles-lettres, I 859 .

"Coronatio Hierosolimitana I 229." In Monumenta Germaniae Historica Constitutiones et Acta Publica Imperatorum et Regum, edited by Ludwig Weiland. Vol. 2. Hannover: Impensis Bibliopolii Aulici Hahniani, i 896.

"De gloriosa pace et treugis inter Christianos et Sarracenos per comitem Ricardum captis." In Matthew Paris, Chronica majora. Vol. 4 of Rolls Series 57. London: Longman, I 872 - I 883 .

Delaville Le Roulx, Joseph., edit. "Cartulaire général de l'Ordre des Hospitaliers de SaintJean de Jérusalem ( I I oo- I 3 I o).” Vol. i. Paris: E. Leroux, i 894.

Edbury, Peter W., edit. "The Conquest of Jerusalem and the Third Crusade: Sources in Translation.” Aldershot: Ashgate, 1996.

"L'Estoire de Eracles Empereur et la Conqueste de la Terre d'Outremer." In Recueil des Historiens des Croisades. Historiens Occidentaux. Vol. 2. Paris: Académie des inscriptions et belles-lettres, I 859 .

Hassler, Konrad D., edit. "Fratris Felicis Fabri Evagatorium in Terrae Sanctae, Arabiae et Egypti peregrinationem.” Vol. I. Stuttgart: Litterarischen Vereins, I 843.

Hirsch, Theodor., edit. "Die Chronik der Vier Orden von Jerusalem.” In Scriptores rerum Prussicarum. Die Geschichtsquellen der Preußischen Vorzeit bis zum Untergange der Ordensherrschaft, edited by Walther Hubatsch and Udo Arnold. Vol. 6. Frankfurt/ Main: Minerva, 1968.

Hirsch, Theodor., edit. "Die Jüngere Hochmeisterchronik." In Scriptores rerum Prussicarum. Die Geschichtsquellen der Preussischen Vorzeit bis zum Untergane der Ordensherrschaft, edited by Theodor Hirsch, Max Toeppen and Ernst Strehlke. Vol. 5. Leipzig: Von Hirzel, i 874 (repr.: Frankfurt/Main: Minerva, I 965).

Huillard-Bréholles, Jean L. A., edit. "Historia Diplomatica Frederici Secundi." Vol. 3. Turin: Bottega d'Erasmo, 1963.

La Monte, John L., trans. "Philip de Novare, The Wars of Frederick II against the Ibelins in Syria and Cyprus." New York: Columbia University Press, 1936.

Mas Latrie, Louis., edit. “Chronique d'Ernoul et de Bernard le Trésorier.” Paris: J. Renouard, I $87 \mathrm{I}$. 
Huygens, Robert B. C., edit. "Peregrinationes Tres, Saewulf, John of Würzburg, Theodericus." In Corpus Christianorum Continuatio Mediaeualis. Vol. I 39. Turnhout: Brepols, I994.

Perlbach, Max., edit. "Die Statuten des Deutschen Ordens nach seinen ältesten Handschriften." Halle: M. Niemeyer, I 890.

Richards, Donald S., trans. "The Chronicle of Ibn al-Athir for the Crusading Period from al-Kamil fi'l-ta'rkikh." Vol. 2. Aldershot: Ashgate, 2008.

Röhricht, Reinhold., edit. "Regesta Regni Hierosolymitani I097-ı 29 I." Innsbruck: Oeniponti Libraria Academica Wagneriana, r 893-1904.

Scholz, Klaus., Wojtecki, Dieter., trans. "Peter von Dusburg Chronik des Preussenlandes." (Ausgewählte Quellen zur deutschen Geschichte des Mittelalters XXV). Darmstadt: Wissenschaftliche Buchgesellschaft, I 984.

Söllweck, Matthias., edit. "Pauli Waltheri Guglingensis Itinerarium.” Tübingen: H. Laupp, I 882.

Stevenson, Joseph., edit. "Chronica de Mailros." Edinburgh: Bannatyne, r 835.

Strehlke, Ernst., edit. "Tabulae Ordinis Theutonici ex tabularii regii Berolinensis codice potissimum.” Berlin: Weidmann, I 869 (repr.: Toronto, Jerusalem, I 975 ).

Abulafia, David. Frederick II. A Medieval Emperor. London: Allen Lane the Penguin Press, I 988.

Amiri, Avner. The German Church in Jerusalem, the Old City, a land program, general provisions for conservation. Israel Antiquities Authority - the Conservation unit. Jerusalem: Israel Antiquities Authority Publications, 2009 (Hebrew).

Asbridge, Thomas. The First Crusade, A New History. London: Free Press, 2004.

Arnold, Udo. "Deutschordenshistoriographie im Deutschen Reich." In Die Rolle der Ritterorden in der mittelalterlichen Kultur (Ordines Militares. Colloquia Torunensia Historica III), edited by Zenon H. Nowak, 65-87. Toruń: TNT, i 985.

Arnold, Udo. "Entstehung und Frühzeit des Deutschen ordens." In Die geistlichen Ritterorden Europas, edited by Josef Fleckenstein and Manfred Hellmann, 8I-I07. Sigmaringen: Thorbecke, I980.

Arnold, Udo. "Jerusalem und Akkon. Zur Frage von Kontinuität oder Neugründung des Deutschen Ordens I I90.” Mitteilungen des Instituts für österreichische Geschichtsforschung 86 (1978): 416-432.

Arnold, Udo. "Ritter und Priester." In Acht Jahrhunderte Deutscher Orden in Nordwesteuropa (Ausstellungkatalog), edited by Udo Arnold, Alden Biesen: Brepols, I 992.

Arnold, Udo. "Die Staufer und der Deutsche Orden." In Medieval Spirituality in Scandinavia and Europe. A Collection of Essays in Honour of Tore Nyberg, edited by Lars Bisgaard, Carsten S. Jensen and John Lind, I45-155. Odense: Odense University Press, $200 \mathrm{I}$.

Arnold, Udo. "Vom Feldspital zum Ritterorden, Militarisierung und Territorialisierung des Deutschen Ordens ( I 190 - ca. I 240).” In Balticum. Studia z dziejów polityki, gosp- 
odarki i kultury XII-XVII wieku, ofiarowane Marianowi Biskupowi w siedemdziesiata. rocznice urodzin, edited by Zenon H. Nowak, 25-36. Torun: TNT, I 992.

Baldwin, Marshall. W. "Franciscan Missions to the East in the Thirteenth and Fourteenth Centuries." In History of the Crusades, The Impact of the Crusades on the Near East, edited by Norman P. Zacour and Harry W. Hazard. Vol. 5, 452-489. Madison: The University of Wisconsin Press, I 985.

Barber, Malcolm. "The Origins of the Order of the Temple." Studia Monastica I 2 ( I 970 ), 2: $219-240$.

Ben Dov, Meir. “The Restoration of St. Mary's Church of the German Knights in Jerusalem." In Ancient Churches Revealed, edited by Yoram Tsafrir, I 40- I 42. Jerusalem: Israel Exploration Society, 1993.

Berkovich, Ilya. "Templars, Franks, Syrians and the Double Pact of I 244." In The Military Orders, edited by Peter Edbury. Vol. 5: Politics and Power, 83-94. Farnham: Ashgate, 2012.

Berkovich, Ilya., Re'em, Amit. "The Location of the Crusader Hospital in the Muristan: A Reassessment." In The ancient Remains below the Church of the Redeemer, the Muristan and its Surroundings, edited by Dieter Vieweger and Shimon Gibson, 193-220. Oxford: Oxford University Press, 2016.

Boas, Adrian J. Jerusalem in the Time of the Crusades: society, landscape, and art in the Holy City under Frankish rule. London: Routledge, $200 \mathrm{I}$.

Bulst-Thiele, Marie-Luise. "Zur Geschichte der Ritterorden und des Königreichs Jerusalem im I 3 Jahrhundert bis zur Schlacht bei La Forbie am 17. Okt. I 244." Deutsches Archiv 22 (1966): 197-226.

Burgtorf, Jochen. The Central Convent of Hospitallers and Templars, History, Organization, and Personnel (1099/II20-1310). Leiden: Brill, 2008.

Cahen, Claude. "The Turks in Iran and Anatolia before the Mongol Invasions." In A History of the Crusades, The Later Crusades, II89-I3II, edited by Robert L. Wolff and Harry W. Hazard. Vol. 2, 660-692. Philadelphia: University of Pennsylvania Press, 1962 .

Carls, Weiland. Felix Fabri, Die Sionpilger, Berlin: E. Schmidt Verlag, I 999.

Czaja, Roman. "Die Identitat des Deutschen Ordens in Preussen." In Cura Animarum, Seelsorge im Deutschordensland Preußen, edited by Stefan Samerski, 44-57. Köln: Böhlau, 20 I 3.

Delano-Smith, Catherine. "The intelligent pilgrim: maps and medieval pilgrimage to the Holy Land." In Eastward Bound, Travel and Travellers, I050-1550, edited by Rosamund Allen, I07-I30. Manchester: Manchester University Press, 2004.

Edelkopf, Marcus. The German Church in the Old City of Jerusalem: conservation and development plan, Israel Antiquities Authority. Jerusalem: Israel Antiquities Authority Publications, 2008 (Hebrew).

Edgington, Susan. "Administrative Regulations for the Hospital of St. John in Jerusalem dating from the i I 80 s." Crusades 4 (2005): 27-34. 
Ellenblum, Ronnie. "Frankish Castles, Muslim Castles, and the Medieval Citadel of Jerusalem." In Laudem Hierosolymitani. Studies in Crusades and Medieval Culture in Honour of Benjamin Z. Kedar, edited by Iris Shagrir, Ronnie Ellenblum and Jonathan Riley-Smith, 93-r 09. Aldershot: Ashgate 2007.

Elm, Kasper. "Kanoniker und Ritter vom Heiligen Grab. Ein Beitrag zur Frühgeschichte der Palästinensischen Ritterorden.” In Die geistlichen Ritterorden Europas (Vorträge und Forschungen XXVI), edited by Josef Fleckenstein and Manfred Hellmann, I 4 I- I69. Sigmaringen: Thorbecke, I 980.

Favreau-Lilie, Marie-Luise. “The German Empire and Palestine: German pilgrimages to Jerusalem between the I 2 th and I 6th century." Journal of Medieval History 2 I (I 995): $321-342$.

Favreau, Marie-Luise. Studien zur Frühgeschichte des Deutschen Ordens. Stuttgart: E. Klett, I 974 .

Friedman, Yvonne. "Peacemaking, Perceptions and Practices in the Medieval Latin East." In The Crusades and the Near East, edited by Conor Kostick, 229-257. London: Routledge, 20 I I.

Friedman, Yvonne. "Sacred and Secular in the Fourteenth-Century Pilgrims' Conception of the Holy Land.” In Eretz Israel in the Mamluk Period, edited by Yosef Drori, I $28-$ - I 4 I. Jerusalem: Yad Izhak Ben Zvi, I 993 (Hebrew).

Frankel, Rafael. "Topographical Notes on the Territory of Acre in the Crusader Period." Israel Exploration Journal 38 ( 1988), 4: 249-272.

Grabiner, Eshter. “The Elbow Column: An Original Crusader Creation.” In Knights of the Holy Land, The Crusader Kingdom of Jerusalem, edited by Silvia Rozenberg, I $92-$ 20 I. Jerusalem: The Israel Museum, I 999.

Hasecker, Jyri. Die Johanniter und die Wallfahrt nach Jerusalem (1480-1522). Göttingen: V\&R Unipress, 2008.

Hechelhammer, Bodo. Kreuzzug und Herrschaft unter Friedrich II. Handlunsräume von Krreuzzugspolitik (I2IS-I230) (Mittelalter-Forschungen I3). Ostfildern: Jan Thorbecke Verlag, 2004.

Herde, Peter. "Die Kampfe bei den Hornern von Hittin and der Untergang des Kreuzritterheeres (3. and 4. Juli I I 87). Eine historisch-topographische Studie." Römische Quartalschrift für christliche und Altertumskunde und Kirchengeschichte 6I (I 966): I -50 .

Hubatsch, Walther. Quellen zur Geschichte des Deutschen Ordens (Quellensammlung zur Kulturgeschichte 5). Göttingen: Musterschmidt, I 954.

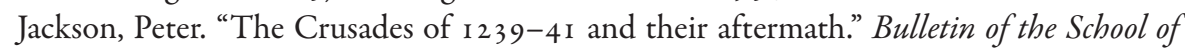
Oriental African Studies 50 (1 987): 32-60.

Johns, Cedric N. Pilgrim' Castle (Atlit) David's Tower (Jerusalem) and Qal'at ar-Rabad (Ajlun), edited by Denys Pringle, Aldershot: Ashgate, 1997.

Jotischky, Andrew. "The Franciscan Return to the Holy Land (1333) and Mt Sion: Pilgrimage and the Apostolic Mission" In The Crusader World, edited by Adrian J. Boas, 24I-250. London: Routledge, 20 I 6. 
Kedar, Benjamin Z. "A Note of Jerusalem's Bīmāristan and Jerusalem's Hospital." In The Hospitallers, the Mediterranean and Europe: Festschrift for Anthony Luttrell, edited by Karl Borchardt, Nikolas Jaspert and Helen J. Nicholson, 7-I I. Aldershot: Ashgate, 2007.

Kedar, Benjamin Z., Pringle, Denys. “ı 099- I 1 87: The Lord's Temple (Templum Domini) and Solomon's Palace (Palatium Salomonis)." In Where heaven and earth meet: Jeruslaem's sacred esplanade, edited by Oleg Grabar, I32-149. Jerusalem: Yad Izhak Ben-Zvi, 2009.

Lotan, Shlomo. "Governing the Teutonic Order from "Outremer" - The Teutonic Headquarters Competing in the Last Era of the Latin Kingdom of Jerusalem." In Herrschaft, Netzwerke, Brüder des Deutschen Ordens in Mittelalter und Neuzeit. Vorträge der Tagung der Internationalen Historischen Kommission zur Erforschung des Deutschen Ordens in Marburg 2010 (Quellen und Studien zur Geschichte des Deutschen Ordens 72), edited by Klaus Militzer, 25-38. Weimar: VDG, 2012.

Lotan, Shlomo. "The Symbolism of Jerusalem in the Traditions of the Teutonic Military Order." Zapiski Historyczne 75 (2010), 4: 7-18.

Lower, Michael. The Baron's Crusade. A Call to Arms and its Consequences. Philadelphia: University of Pennsylvania Press, 2005.

Mashiah, Avi. "The Conservation of David's Tomb on Mount Sion." Dvar Avar (July 2013): 14-17 (Hebrew).

Mastnak, Tomaz. Crusading Peace. Christendom, the Muslim World, and Western Political Order. Berkeley: University of California Press, 2002.

Metav, Ami. Jerusalem - one square kilometer: the Old City - a guide to the sites. Jerusalem: Ad-Or Pub., 2015 (Hebrew).

Militzer, Klaus. Von Akkon zur Marienburg, Verfassung, Verwaltung und Sozialstruktur des Deutschen Ordens II $00-1309$. Marburg: Elwert, 1999.

Mitchell, Piers D. Medicine in the Crusades, Warfare, Wounds and the Medieval Surgeon. Cambridge: Cambridge University Press, 2004.

Morton, Nicholas, E. The Teutonic Knights in the Holy Land IIgo-I29I. Woodbridge: Boydell Press, 2009.

Müller, Gerard. Jerusalem oder Akkon? Über den Anfang des Deutschen Ordens nach dem gegenwärtigen Stand der Forschung. Bad Münstereifel: Arnold, 1989.

Nicholson, Helen. Templars, Hospitallers, and Teutonic Knights: Images of the Military Orders, II28-I29I. Leicester: Leicester University Press, I995.

Noonan, Thomas. The Road to Jerusalem: Pilgrimage and Travel in the Age of Discovery. Philadelphia: University of Pennsylvania Press, 2007.

Ovadiah, Asher. "A Crusader Church in the Jewish Quarter of Jerusalem." Eretz Israel I I (I973): 208-2 I 2 (Hebrew).

Powell, James M. "Patriarch Gerold and Frederick II: The Matthew Paris Letter." Journal of Medieval History 25 ( 1999), I: 19-26.

Prawer, Joshua. Histoire du Royaume Latin de Jérusalem, Tome II. Paris: Editions du Centre national de la recherche scientifique, 1975. 
Pringle, Denys. "Pilgrimage to Jerusalem and the Holy Land, r I 87- I 29 r." Farnham: Ashgate, $20 \mathrm{I} 2$.

Pringle, Denys. "The Layout of the Jerusalem Hospital in Twelfth Century: Further Thoughts and Suggestions." In The Military Orders: By Land and by Sea, edited by Judi Upton-Ward. Vol. 4., 9I - I I o. Aldershot: Ashgate, 2008.

Pringle, Denys. "The Military Orders in the Cities of the Holy Land." In Les Ordres Militaires dand la Ville Médiévale (1100-1350), edited by Damien Carraz, 79-95. Clermont-Ferrand: Presses universitaires Blaise Pascal, 2013.

Prutz, Hans. Die Besitzungen des Deutschen Ordens im Heligen Land. Leipzig: Brockhaus, I 877 .

Re'em, Amit. "Jerusalem, Mount Sion." Hadashot Arkheologiyot, Excavations and Surveys in Israel I 24 (201 2). Accessed November 3 I, 20 I 2.

Richard, Jean. The Latin Kingdom of Jerusalem. Vol. II A, B. Amsterdam: North-Holland Pub., i 979 .

Ross, Linda. "Frederick II: Tyrant or Benefactor of the Latin East?" Al Masāq is (2003), 2: I 49-I 59 .

Röhricht, Reinhold. "Die Deutschen im Heiliger Land :chronologisches." In Chronologisches Verzeihnis derjenigen Deutschen, welche als Jerusalempilger und Kreuzfahrer sischer nachzuweisen oder wahrscheinlich anzusehen als Jerusalempilger und Kreuzfahrer. 650-I 291. Aalen: Scientia Verlag, i 968.

Rudy, Kathryn M. Virtual Pilgrimages in the Convent: Imagining Jerusalem in the Late Middle Ages. Turnhout: Brepols, 20 I I.

Sarnowsky, Jürgen. "Historical writing in militry orders I 2th-16th centuries." In As Ordens Militares e as Ordens de Cavaleria entre o Ocidente e o Oriente, Actas do V Encontro sobre Ordens Militares, Palmela, I 5 a i 8 de Fevereiro 2006, edited by Isabel C. F. Fernandes, I09-I I 9. Palmela: GesOS, Municipio de Palmela, 2009.

Sarnowsky, Jürgen. "Das historische Selbstverständnis der geistlichen Ritterorden." Zeitschrift für Kirchengeschichte I 10 ( 1999 ): 3 I 5-330.

Schein, Sylvia. "Between Mount Moriah and the Holy Sepulchre: The Changing Traditions if the Temple Mount in the Central Middle Ages." Traditio 50 (1 984 ): I 75 - I 95.

Schein, Sylvia. "Latin Hospices in Jerusalem in the Late Middle Ages." Zeitschrift des Deutschen Palastina-Vereins i I (1985), i: 82-92.

Schein, Sylvia. "From the 'City of the Holy Sepulchre' to the 'City of the Humanity of Christ." In Gateway to the Heavenly City: Crusader Jerusalem and the Catholic West (1099-1187), edited by Sylvia Schein, 63-90. Aldershot: Ashgate, 2005.

Takayama, Hiroshi. "Frederick II's Crusade: an example of Christian - Muslim diplomacy." Mediterranean Historical Review 25 (2010), 2: 169-1 85.

Tyerman, Christopher. God's War. A New History of the Crusades. Cambridge (Mass.): Belknap Press of Harvard University Press, 2006.

Van Cleve, Thomas C. The Emperor Frederick II of Hohenstaufen Immutator Mundi. Oxford: Clarendon Press, i 972. 
Weiler, Björn. "Gregory IX, Frederick II, and the Liberation of the Holy Land." In The Holy Land, Holy Lands, and Christian History, edited by Robert N. Swanson, I92-206. Rochester: Boydell \& Brewer, 2000.

Wichert, Gabriele. "Die Spiritualität des Deutschen Ordens in seiner mittelalterlichen Regeln." In Die Spiritualität der Ritterorden im Mittelalter (Ordines Militares. Colloquia Torunensia Historica VII), edited by Zenon H. Nowak, I 3 I-1 46. Toruń: TNT, 1993.

Wightman, Gregory J. The Walls of Jerusalem, From the Canaanites to the Mamluks. Sydney: Meditarch, 1993.

Wüst, Marcus. Studien zum Selbstverständnis des Deutschen Ordens im Mittelalter (Quellen und Studien zur Geschichte des Deutschen Ordens 73). Weimar: VDG, 2013.

Zrenner, Claudia. Die Berichte der europäischen Jerusalempilger 1475-I50o. Frankfurt/ Main.: P.D. Lang, $198 \mathrm{I}$.

\section{ABstract \\ The Status and the Position of the German Structure in Jerusalem in the $I 2^{\text {th }}-13^{\text {th }}$ Centuries}

One of the interesting subjects in the study of Jerusalem during the Crusader period is the status and position of the German Structure located in the southeastern part of the Jerusalem. This article attempts to describe the phases in the establishment of the German structure in the I 2 th century, as well as its status in the mid-I 3 th century till the demise of the city at the end of the Crusader presence in Jerusalem. This article describes also the history and the tradition of the German structure in its environment in Jerusalem. In this research I will try to direct and to observe if this German structure in its compound left any mark on the Teutonic Order tradition or its spiritual literature, which may link Jerusalem to the heritage and tradition of the Teutonic Knights in the late Middle Ages. 